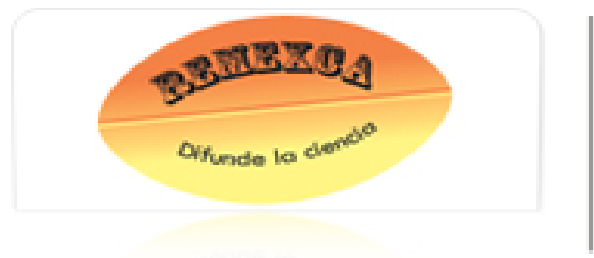

Revista Mexicana de Ciencias Agrícolas

ISSN: 2007-0934

revista_atm@yahoo.com.mx

Instituto Nacional de Investigaciones

Forestales, Agrícolas y Pecuarias

México

López-Pérez, Carlos Antonio; Valdez-Aguilar, Luis Alonso; Robledo-Torres, Valentín; Mendoza-

Villarreal, Rosalinda; Castillo-Gonzalez, Ana María

El calcio imparte tolerancia a alta conductividad eléctrica en Lisianthus (Eustoma grandiflorum Raf.

Shinn.)

Revista Mexicana de Ciencias Agrícolas, vol. 5, núm. 7, septiembre-noviembre, 2014, pp. 1193-1204

Instituto Nacional de Investigaciones Forestales, Agrícolas y Pecuarias

Estado de México, México

Disponible en: http://www.redalyc.org/articulo.oa?id=263131533005

Cómo citar el artículo

- Número completo

- Más información del artículo

- Página de la revista en redalyc.org

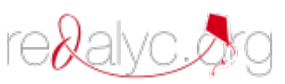

Sistema de Información Científica

Red de Revistas Científicas de América Latina, el Caribe, España y Portugal

Proyecto académico sin fines de lucro, desarrollado bajo la iniciativa de acceso abierto 


\title{
El calcio imparte tolerancia a alta conductividad eléctrica en Lisianthus (Eustoma grandiflorum Raf. Shinn.)*
}

\section{Calcium imparts tolerance to high electrical conductivity in Lisianthus (Eustoma grandiflorum Raf. Shinn.)}

\author{
Carlos Antonio López-Pérez ${ }^{1}$, Luis Alonso Valdez-Aguilar ${ }^{1 \S}$, Valentín Robledo-Torres ${ }^{1}$, Rosalinda Mendoza-Villarreal ${ }^{1}$ y Ana \\ María Castillo-Gonzalez ${ }^{2}$
}

${ }^{1}$ Departamento de Horticultura-Universidad Autónoma Agraria Antonio Narro. Calzada Antonio Narro 1923, Col. Buenavista, Saltillo, Coahuila, México. C. P. 25315. (gtonarro@live.com.mx; luisalonso.valdez@uaaan.mx; varoto@prodigy.net.mx; rosalindamendoza@hotmail.com). ${ }^{2}$ Universidad Autónoma Chapingo-Departamento de Fitotecnia. Carretera México-Texcoco km 38.5. (anasofiacasg@hotmail.com). ${ }^{\S}$ Autor para correspondencia: luisalonso.valdez@uaaan.mx.

\section{Resumen}

Se ha reportado que el calcio $(\mathrm{Ca})$ tiene un efecto moderador de los efectos de la salinidad ya que mantiene la integridad de las membranas celulares y reduce la pérdida de potasio $(\mathrm{K})$. Lisianthus es una planta ornamental cuyo hábitat sugiere que puede adaptarse a condiciones extremas. El presente estudio se estableció para evaluar si el Ca $\left(9\right.$ y 13 meq L $\left.^{-1}\right)$ influye en la tolerancia de lisianthus a una mayor conductividad eléctrica (CE) $\left(2.5,4,6 y 8 \mathrm{dSm}^{-1}\right)$ en la solución nutritiva. Elpeso seco se redujo cuando se elevó la $\mathrm{CEa} 4 \mathrm{dSm}^{-1}$ independientementedel nivel de $\mathrm{Ca}$; sin embargo, la biomasa mostró una recuperación cuandola CEaumentó hasta 6 y $8 \mathrm{dS} \mathrm{m}^{-1}$ en plantas con $13 \mathrm{meq}$ $\mathrm{L}^{-1} \mathrm{de} \mathrm{Ca}$. Las plantas con Ca suplementario mantuvieron una mayor concentración de los pigmentos fotosintéticoscuando la CEfue de 6 y $8 \mathrm{dSm}^{-1}$. Independientemente de la concentración de $\mathrm{Ca}$, la $\mathrm{CE}$ afectó la fotosíntesis neta al disminuir cuando la CEaumentó a $4 \mathrm{dS} \mathrm{m}^{-1}$. El contenido relativo de agua(CRA) en hojas jóvenes de plantas suplementadas conniveles adicionales de Ca aumentó cuando se trataron con solucionescon CEmayor de $4 \mathrm{dS} \mathrm{m}^{-1}$, lo que estuvo asociado con un mayor potencial hídrico. La concentración de nitrógeno, K, Ca y magnesio fue afectada por la $\mathrm{CE}$ aunque esta se recupera con $\mathrm{Ca}$ adicional. Los resultados indican que lisianthus tolera niveles altos de salinidad solo si se adicionan cantidades suplementarias de Ca.

\section{Abstract}

It has been reported that calcium $(\mathrm{Ca})$ has a moderating effect on the effects of salinity, and which maintains the integrity of cellular membranes and reduce the loss of potassium $(\mathrm{K})$. Lisianthus is an ornamental plant whose habitat suggests that it can adapt to extreme conditions. This study set out to assess whether the $\mathrm{Ca}$ (9 and $13 \mathrm{meq} \mathrm{L}^{-1}$ ) influences lisianthus tolerance to increased electrical conductivity (EC) $(2.5$, 4, 6 and $8 \mathrm{dS} \mathrm{m}^{-1}$ ) in the nutrient solution. The dry weight was reduced when $\mathrm{EC} 4 \mathrm{dS} \mathrm{m}^{-1}$ regardless of the level of $\mathrm{Ca}$ was raised; however, the biomass was recovered when the EC increased to 6 and $8 \mathrm{dS} \mathrm{m}^{-1}$ plants with $13 \mathrm{meq} \mathrm{Ca} \mathrm{L}^{-1}$ of plants with extra $\mathrm{Ca}$ maintained a greater concentration of photosynthetic pigments when the EC was 6 and $8 \mathrm{dS} \mathrm{m}^{-1}$. Regardless of the concentration of $\mathrm{Ca}$, the net photosynthesis affected EC to decrease when the EC increased to $4 \mathrm{dS}$ $\mathrm{m}^{-1}$. The relative water content (RWC) in young leaves of plants supplemented with additional levels of $\mathrm{Ca}$ increased when treated with solutions with EC greater than $4 \mathrm{dS}$ $\mathrm{m}^{-1}$, which was associated with a higher water potential. The concentration of nitrogen, $\mathrm{K}, \mathrm{Ca}$ and magnesium was affected by the $\mathrm{EC}$ but this is recovered with additional $\mathrm{Ca}$. The results indicate that lisianthus high salinity tolerant only if additional quantities are added $\mathrm{Ca}$.

\footnotetext{
* Recibido: enero de 2014 
Palabras clave: contenido relativo de agua, hidroponia, ornamentales, potencial hídrico, salinidad, tolerancia al estrés.

\section{Introducción}

La salinidad es uno de los principales factores abióticos que limitan la productividad agrícola debido a que la mayoría de las plantas cultivadas son sensibles a esta condición. El problema de la salinidad se ha incrementado considerablemente debido a los efectos del riego ya que para garantizar el suministro de agua se ha implementado el uso de agua de deficiente calidad. El efecto más evidente del estrés salino es la reducción de la capacidad de absorción de agua, manifestándose en una disminución de la expansión foliar y el potencial osmótico y de turgencia (Marschner, 1995). Este estrés genera señales químicas en la célula, como el aumento del calcio (Ca) libre intracelular, lo cual desencadena respuestas adaptativas para contrarrestar el efecto adverso (Hasegawa et al., 2000).

El Ca tiene es un moderador de los efectos de la salinidad ya que permite mantener la integridad de las membranas celulares y es un cofactor de varias enzimas (Rengel, 1992). Se ha demostrado que el Ca protege las membranas contra los efectos adversos del sodio $(\mathrm{Na})$, manteniendo así su integridad y reduciendo al mínimo la pérdida de K (Cramer et al., 1985).

Lisianthus (Eustoma grandiflorum Raf. Shinn.) es una planta ornamental que se ha posicionado en el gusto de los consumidores a nivel mundial (Kiamohammadi, 2011). Su hábitat natural, las zonas áridas y semiáridas del sur de Estados Unidos de América y norte de México, sugiere que puede adaptarse a condiciones más extremas que la mayoría de las especies florícolas cultivadas, debido a su tolerancia a una conductividad eléctrica (CE) tan alta como $8 \mathrm{dS} \mathrm{m}^{-1}$, como lo reportan Valdez-Aguilar et al. (2013); sin embargo, tales estudios se efectuaron combinando diferentes concentraciones de iones como sulfato $\left(\mathrm{SO}_{4}{ }^{2-}\right)$, magnesio $(\mathrm{Mg}), \mathrm{Ca}, \mathrm{Na}$, y cloro $(\mathrm{Cl})$, por lo que no es posible determinar si el efecto de alguno de estos interactúa con la respuesta de las plantas a la salinidad. Por este motivo, en el presente estudio se evaluó la posibilidad de que el Ca influya en la tolerancia de lisianthus a una mayor CE en la solución nutritiva.
Keywords: relative watercontent, hydroponics, ornamental, water potential, salinity stress tolerance.

\section{Introduction}

Salinity is a major abiotic factors limiting agricultural productivity because most crop plants are sensitive to this condition. The problem of salinity has increased considerably due to the effects of irrigation and to ensure that the water supply has implemented the use of poor quality water. The most obvious effect of salt stress is the reduction of water absorption capacity, manifested in adecrease in leaf expansion and osmotic potential, and turgor (Marschner, 1995). This stress generates chemical signals in the cell, such as increased calcium $(\mathrm{Ca})$ free intracellular, which triggers adaptive to counteract the adverse effect responses (Hasegawa et al., 2000).

The $\mathrm{Ca}$ is a moderator of the effects of salinity because it maintains the integrity of cell membranes and is a cofactor for several enzymes (Rengel, 1992). It has been shown that Ca protects membranes from the adverse effects of sodium $(\mathrm{Na})$, thereby maintaining its integrity and minimizing loss of K (Cramer et al., 1985).

Lisianthus (Eustoma grandiflorum Raf. Shinn.) is an ornamental plant that has been positioned in the taste of consumers worldwide (Kiamohammadi, 2011). Its natural habitats, arid and semi-arid areas of the southern United States and northern Mexico, suggests that itcan adapt to more extreme than most grown floricultural species conditions, due to its tolerance to electrical conductivity (EC) as high as $8 \mathrm{dS} \mathrm{m}^{-1}$, as reported Valdéz-Aguilar et al. (2013); however, such studies combining different concentrations of ions such as sulfate $\left(\mathrm{SO}_{4}{ }^{2}\right)$ were carried out, magnesium $(\mathrm{Mg}), \mathrm{Ca}, \mathrm{Na}$, and chlorine (Cl), so it is not possible to determine whether the effect of one of these interacts with the plant response to salinity. Therefore, in this study the possibility of the $\mathrm{Ca}$ influence lisianthus tolerance to higher EC in the nutrient solution was evaluated.

\section{Materials and methods}

The study was conducted in a greenhouse with polycarbonate in Saltillo campus of the Universidad Autónoma Agraria Antonio Narro (UAAAN) $\left(25^{\circ} 22^{\prime \prime} \mathrm{N}, 101^{\circ} 02^{\prime \prime} \mathrm{W}\right.$, altitude 


\section{Materiales y métodos}

El estudio se realizó en un invernadero con cubierta de policarbonato en el campus Saltillo de la Universidad Autónoma Agraria Antonio Narro (UAAAN) $\left(25^{\circ} 22^{\prime}\right.$ de latitud norte, $101^{\circ} 02$ " longitud oeste, altitud de $1742 \mathrm{~m}$ ). Durante el desarrollo del estudio se registró una temperatura promedio de $22^{\circ} \mathrm{C}$ (máxima de $33^{\circ} \mathrm{C}$, mínima de $15^{\circ} \mathrm{C}$ ), una humedad relativa de158\%(máxima de $80 \%$ y mínima de $32 \%$ ) y una radiación fotosintéticamente activa de $307 \mu \mathrm{mol} \mathrm{m}^{-2} \mathrm{~s}^{-1}$.

Plantas de lisianthus 'ABC Blue' se trasplantaron el 21 de marzo de 2013 cuando presentaban una altura promedio de $4 \mathrm{~cm}$, colocándose 10 de ellas en contenedores de plástico rígido ( $33 \mathrm{~cm}$ de ancho, $51 \mathrm{~cm}$ de largo y $27 \mathrm{~cm}$ de altura). Alos contenedores se les agregó $40 \mathrm{~L}$ de un sustrato inerte (perlita) previamente humedecido con agua potable. Se colocaron 10 plantas por contenedor y cada uno de estos fue colocado sobre una mesa elevada con un sistema hidropónico recirculante. La distancia entre plantas fue de $8 \mathrm{~cm}$ y entre hileras de $15 \mathrm{~cm}$.

Durante 15 días posteriores al trasplante, las plantas se regaron cada 30 min con una solución nutritiva con la formulación de Steiner (1984), después de lo cual dio inicio la aplicación de los tratamientos. Estos consistieron en ocho soluciones con diferente $\mathrm{CE}$ lograda mediante la manipulación de la concentración de $\mathrm{SO}_{4}{ }^{2-}, \mathrm{Cl}, \mathrm{Mg}, \mathrm{NaCly} \mathrm{Ca}$ (Cuadro 1). El resto de los nutrimentos se aportaron de acuerdo a la formulación de Steiner (1984). La CE de las soluciones nutritivas fue de 2.5, 4, 6 y $8 \mathrm{dS} \mathrm{m}^{-1}$ y cada una de ellas contenía dos niveles de $\mathrm{Ca}\left(9\right.$ y $\left.13 \mathrm{meq} \mathrm{L}^{-1}\right)$. Para mantener una CE consistente a las soluciones con más $\mathrm{Ca}$ se les redujo proporcionalmente la concentración de $\mathrm{Mg}$ y $\mathrm{Na}$. El pH y alcalinidad de las soluciones fue ajustado a 6.3 y $1 \mathrm{meq} \mathrm{L}^{-1}$, respectivamente.
$1742 \mathrm{~m}$ ). During the course of the study an averagetemperature of $22{ }^{\circ} \mathrm{C}$ (maximum $33{ }^{\circ} \mathrm{C}$, minimum $15{ }^{\circ} \mathrm{C}$ ), relative humidity of $58 \%$ (maximum $80 \%$ and minimum $32 \%$ ) and photosyntheticallyactiveradiationwasrecorded $307 \mu \mathrm{molm}^{-2} \mathrm{~s}^{-1}$.

Lisianthus plants 'ABC Blue' were transplanted on March 21,2013 when they had an average height of $4 \mathrm{~cm}, 10$ are standing in rigid plastic containers $(33 \mathrm{~cm}$ wide, $51 \mathrm{~cm}$ long and $27 \mathrm{~cm}$ high). To the containers $40 \mathrm{~L}$ of an inert substrate (perlite) moistened with water were added. 10 plants per container and each of these was placed on an elevated table with a recirculating hydroponic system is placed. Row distance was $8 \mathrm{~cm}$ and $15 \mathrm{~cm}$ between rows.

For 15 days after transplantation, the plants were watered every 30 min with a nutrient solution with the formulation of Steiner (1984), after which began the application of treatments. These consisted of eight solutions with different $\mathrm{CE}$ achieved by manipulating the concentration of $\mathrm{SO}_{4}{ }^{2-}, \mathrm{Cl}$,

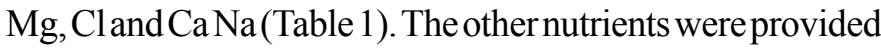
according to the formulation of Steiner (1984). The EC of the nutrient solutions was 2.5, 4, 6 and $8 \mathrm{dS} \mathrm{m}^{-1}$ and each containing two levels of $\mathrm{Ca}\left(9\right.$ and $\left.13 \mathrm{meq} \mathrm{L}^{-1}\right)$. To maintain a consistent $\mathrm{EC}$ solutions more proportionately reduced $\mathrm{Ca}$ concentration of $\mathrm{Mg}$ and $\mathrm{Na}$. The $\mathrm{pH}$ and alkalinity of the solutions was adjusted to 6.3 and $1 \mathrm{meq} \mathrm{L}^{-1}$, respectively.

The nutrient solutions were applied through a system of automated drip irrigation, stored in covered containers with a layer of black plastic to block the entry of light and prevent evaporation and is completely renewed every 10 days. The distribution of nutrient solutions was performed using pipeline hose holder-dropper $16 \mathrm{~mm}$, droppers $2 \mathrm{Lh}^{-1}$ and 8 picks in each container. Irrigation was applied every hour between 8:00 and 18:00 pm and lasted $3 \mathrm{~min}$.

Cuadro 1. Conductividad eléctrica (CE), niveles de calcio (Ca) y composición de las soluciones nutritivas en estudio. Table 1. Electric conductivity (EC), calcium (Ca) and composition of the nutrient solutions under study.

\begin{tabular}{ccccccccc}
\hline \multirow{2}{*}{$\begin{array}{c}\mathrm{CE} \\
\left.(\mathrm{dS} \mathrm{m})^{-1}\right)\end{array}$} & $\mathrm{NO}_{3}^{-}$ & $\mathrm{H}_{2} \mathrm{PO}_{4}^{-}$ & $\mathrm{SO}_{4}^{-2}$ & $\mathrm{Cl}$ & $\mathrm{K}$ & $\mathrm{Mg}$ & $\mathrm{Na}$ & $\mathrm{Ca}$ \\
\cline { 2 - 8 }$(\mathrm{meq} \mathrm{L}$ & & & & \\
\hline 2.5 (testigo) & 12 & 1 & 9.3 & 4.7 & 7 & 5.9 & 5.1 & 9 \\
2.5 & 12 & 1 & 9.3 & 4.7 & 7 & 3.9 & 3.1 & 13 \\
4 & 12 & 1 & 14.5 & 14.5 & 7 & 13 & 13 & 9 \\
4 & 12 & 1 & 14.5 & 14.5 & 7 & 11 & 11 & 13 \\
6 & 12 & 1 & 24.5 & 24.5 & 7 & 23 & 23 & 9 \\
6 & 12 & 1 & 24.5 & 24.5 & 7 & 21 & 21 & 13 \\
8 & 12 & 1 & 34.5 & 34.5 & 7 & 33 & 33 & 9 \\
8 & 12 & 1 & 34.5 & 34.5 & 7 & 31 & 31 & 13 \\
\hline
\end{tabular}


Las soluciones nutritivas se aplicaron mediante un sistema de riego por goteo automatizado, se almacenaron en recipientes cubiertos con una película de polietileno negro para bloquear la entrada de luz y evitar la evaporación, y se renovaron completamente cada 10 días. La distribución de las soluciones nutritivas se realizó a través de mangueras de poliducto porta-gotero de $16 \mathrm{~mm}$, goteros de $2 \mathrm{~L} \mathrm{~h}^{-1}$ y 8 piquetas en cada contenedor. Los riegos se aplicaron cada hora entre las 8:00 y 18:00 hy tuvieron una duración de $3 \mathrm{~min}$.

Al finalizar el experimento se cosecharon todas las plantas de cada unidad experimental para determinar la altura de la planta, el diámetro del tallo, y el número y diámetro de flores (se seleccionó la tercera flor abierta). Posteriormente las plantas se seccionaron en hojas, tallos y flores y se lavaron con agua destilada en dos ocasiones para remover partículas adheridas. Estas secciones se colocaron en bolsas de papel e introducidas en un horno de secado a $70^{\circ} \mathrm{C}$ por $72 \mathrm{~h}$, para registrar el peso una vez que el material ya estaba seco; se calculó el peso seco total.

Durante el desarrollodel experimento serealizóuna medición de la tasa de fotosíntesis neta, la conductancia estomática y la tasa de transpiración (IRGA LI-6200 Licor Inc.). Asimismo, se realizó una medición del potencial hídrico $(\Psi h)$ en una hoja joven y en una hoja madura (primer y último tercio de la planta, respectivamente) con una cámara de presión de scholander. Las lecturas de parámetros fotosintéticos y el $\Psi$ h de la hoja se tomaron a los 90 días después del trasplante entre las 11:00 y 12:00 h del día, considerando una planta por unidad experimental. El contenido relativo del agua (CRA) fue determinado en hojas jóvenes y maduras de las plantas: con un sacabocado de $0.5 \mathrm{~cm}$ de diámetro se cortaron 6 discos de la hoja, los cuales se pesaron y colocaron en agua destilada por $4 \mathrm{~h}$. Posteriormente, se volvieron a pesar y se colocaron en una estufa de secado; se volvieron a pesar y el CRA se calculó con la fórmula: $\mathrm{CRA}=[$ (peso fresco-peso saturado) / (peso saturado-peso seco)] * 100. Para la determinación de carotenoides, clorofila a, by total se muestrearon hojasjóvenes completamente desarrolladas de cada unidad experimental y se extrajeron por el método de Jeffrey y Humphrey (1975).

Se realizó un análisis nutrimental en tejidos de la parte aérea (tallos y hojas) muestreados de cuatro plantas por repetición. Las muestras se lavaron con agua destilada e introducidas en bolsas de papel y a un horno de secado a 70 ${ }^{\circ} \mathrm{C}$, por $72 \mathrm{~h}$. El material seco obtenido se llevó a molienda en un molino Analytical Mill (marca Tekmar Co. modelo A-10). Las muestras de las plantas se homogeneizaron
At the end of the experiment all plants in each experimental unit were harvested to determine plant height, stem diameter, and the number and diameter of flowers (the third open flower was selected). Subsequently plants were sectioned into leaves, stems and flowers and washed with distilled water twice to remove loose particles. These sections were placed in paper bags and introduced into a drying oven at $70{ }^{\circ} \mathrm{C}$ for $72 \mathrm{~h}$, to record the weight once the material was dry; total dry weight was calculated.

During the course of the experiment a measurement of the rate of net photosynthesis, stomatal conductance and transpiration rate (LI-6200 IRGALicor Inc.) was performed. Also, a measure of water potential $(\Psi \mathrm{h})$ was performed on a young leaf and mature leaf (first and last third of the plant, respectively) with a Scholander pressure chamber. Readings of photosynthetic parameters and the $\Psi$ h of the leaf were taken at 90 days after transplantation between 11:00 and 12:00 on day considering one plant per experimental unit. The relative water content (RWC) was determined in young and mature leaves of plants: using a 0 punch of $0.5 \mathrm{~cm}$ of diameter, we took 6 disc of the leaf, which were weighed and placed in distilled water for $4 \mathrm{~h}$. Subsequently, reweighed and placed in a drying oven; reweighed and the CRA was calculated using the formula: $\mathrm{CRA}=[($ fresh weight- weight saturated $) /$ (saturated weight- dry weight )] $* 100$. For the determination of carotenoids, chlorophyll a, and b and total, fully developed young leaves were sampled and each experimental unit were extracted by the method of Jeffrey and Humphrey (1975).

One nutritional analysis was performed on tissues of aerial parts (stems and leaves) sampled four plants per replication. The samples were washed with distilled water and inserted into paper bags and a drying oven at $70^{\circ} \mathrm{C}$ for $72 \mathrm{~h}$. The dry material obtained was milling for Analytical Mill (Tekmar Co. brand model A-10). Plant samples were homogenized to determine the concentration of $\mathrm{N}$ by Kjeldahl method. The concentration of $\mathrm{K}$ in the tissues was determined with a Flame-meter Corning 400, taking a sample of digestate obtained from $0.5 \mathrm{~g}$ of ground sample (Alcántar and Sandoval, 1999). The concentration of phosphorus (P), $\mathrm{Ca}$, and magnesium $(\mathrm{Mg})$ were determined by emission spectrometry inductively coupled plasma (ICP-AES Varian Liberty model) using the diluted extract (1:50) obtained by the acid digestion Dried samples.

The study was conducted under a factorial experiment with a randomized block design. Each of the solutions had three replications and 10 plants per experimental unit. Linear trend 
para determinar la concentración de $\mathrm{N}$ por el método de Kjeldhal. La concentración de $\mathrm{K}$ en los tejidos se determinó con un flamómetro Corning 400, tomando una muestra del digestado obtenido a partir de $0.5 \mathrm{~g}$ de muestra molida (Alcántar y Sandoval, 1999). La concentración de fósforo $(\mathrm{P}), \mathrm{Ca}$, y magnesio $(\mathrm{Mg})$ se determinaron por espectrometría de emisión de plasma acoplado inductivamente (ICP-AES VARIAN, modelo Liberty) utilizando el extracto diluido (1:50) obtenido con la digestión ácida de las muestras secas.

El estudio se realizó bajo un experimento factorial con un diseño de bloques al azar. Cada una de las soluciones contaba con tres repeticiones y 10 plantas por unidad experimental. Se realizó un análisis de tendencias lineal, cuadrático y cubico. Los efectos principales así como la interacción entre los factores (CE, Ca y la interacción $\mathrm{CE} * \mathrm{Ca}$ ) y análisis de tendencias se realizó mediante un ANOVA con el programa Statistical Analysis System (SAS, 2001).

\section{Resultados}

La CE y el Ca no tuvieron un efecto significativo sobre la longitud de las plantas, sin embargo, si se detectó una interacción entre ambos factores (Figura 1). Con 9 meq $\mathrm{L}^{-1}$ de Ca se presentó una tendencia cuadrática que permite observar un efecto benéfico de la salinidad al elevarse la $\mathrm{CE}$ a $4 \mathrm{dS} \mathrm{m}^{-1}$, el cual ya no se observa al incrementarse a 6 y $8 \mathrm{dS} \mathrm{m}^{-1}$. A pesar de la reducción de la longitud de planta a alta CE, esta fue aun superior a la lograda por las plantas del tratamiento testigo. Con niveles de 2.5 a $4 \mathrm{dS}$ $\mathrm{m}^{-1}$ la suplementación de $\mathrm{Ca}$ adicional resultó en una mayor longitud del tallo en comparación con las plantas testigo; $\sin$ embargo, con 9 y con 13 meq $^{-1} \mathrm{de} C a$, una mayor CE estuvo asociada con una disminución en la elongación del tallo, a pesar de lo cual esta fue superior al de las plantas testigo.

El peso seco de tallos, hojas y flores (Cuadro 2), así como el peso seco total (Figura 2) mostraron una respuesta similar. Con $9 \mathrm{meq} \mathrm{L}^{-1} \mathrm{de}$ Ca se presentó una disminución lineal del peso seco total, especialmente cuando se eleva la $\mathrm{CE}$ a $4 \mathrm{dS}$ $\mathrm{m}^{-1}$; esta disminución también se observa en plantas tratadas con Ca suplementario, sin embargo, la tendencia cúbica indica que se presenta una recuperación en la biomasa total cuando la $\mathrm{CE}$ aumentó hasta 6 y $8 \mathrm{dS} \mathrm{m}^{-1}$, prácticamente llegando a niveles comparables a los de la biomasa de las plantas del tratamiento testigo (Figura 2). analysis, quadratic and cubic performed. The main effects and the interaction between factors $(\mathrm{EC}, \mathrm{Ca}$ and $\mathrm{Ca} * \mathrm{EC}$ interaction) and trend analysis was performed by ANOVA using the Statistical Analysis System (SAS, 2001).

\section{Results}

EC and Ca had no significanteffect on the length of the plants; however, an interaction between the two factors (Figure 1) was detected. With $9 \mathrm{meq}^{-1} \mathrm{Ca}$ a quadratic trend that allows to observe a beneficial effect of salinity rise to $\mathrm{EC} 4 \mathrm{dS} \mathrm{m}^{-1}$, which is no longer observed to be increased to 6 and $8 \mathrm{dS} \mathrm{m}^{-1}$ was presented. Despite the reduction in the length of high plantEC, this was still higher than that achieved by the control treatment plants. With values of 2.5 and $4 \mathrm{dS} \mathrm{m}^{-1}$ additional $\mathrm{Ca}$ supplementation resulted in a greater length of the stem as compared to control plants; however, 9 and $13 \mathrm{meq} \mathrm{Ca} \mathrm{L}^{-1}$, higherEC was associated with a reduction in stem elongation, although this was thus higher than that of the control plants.

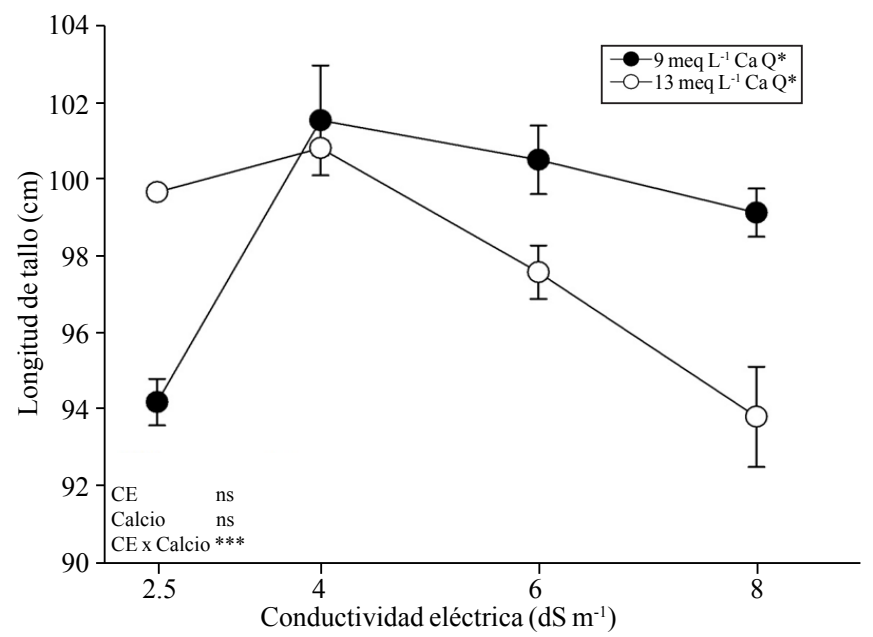

Figura 1. Efecto de la conductividad eléctrica (CE), la concentración de calcio ( $\mathrm{Ca}$ ) en la solución nutritiva e interacción entre ambos factores sobre la longitud de tallo en lisianthus. $Q=$ tendencia cuadrática, * ${ }^{* * *}, \mathrm{~ns}=$ significativo $\operatorname{con} p<0.05, p<$ 0.001 y no significativo, respectivamente. Las barras corresponden al error estándar de la media $(n=3)$.

Figure 1. Effect of the electrical conductivity (EC), concentration of calcium $(\mathrm{Ca})$ in the nutrient solution and interaction between the two factors on the lisianthus stem length. $Q=$ quadratic trend, $*, * * *$, ns $=$ significant with $p<0.05, p<0.001$, not significant, respectively. The bars correspond to the mean standard error $(n=3)$. 
Cuadro 2. Peso seco de tallos, hojas y flores de lisianthus en función de la concentración de calcio (Ca) y la conductividad eléctrica (CE) en la solución nutritiva.

Table 2. Dry weight of stems, leaves and flowers lisianthus depending on the concentration of calcium (Ca) and electrical conductivity (EC) in the nutrient solution.

\begin{tabular}{|c|c|c|c|c|c|c|}
\hline \multirow{3}{*}{$\begin{array}{c}\mathrm{CE} \\
\left(\mathrm{dS} \mathrm{\textrm {m } ^ { - 1 }}\right)\end{array}$} & \multicolumn{2}{|c|}{ Peso seco de tallos (g) } & \multirow{2}{*}{\multicolumn{2}{|c|}{$\frac{\text { Peso seco de hojas }(\mathrm{g})}{\mathrm{Ca}\left(\mathrm{meq} \mathrm{L}^{-1}\right)}$}} & \multicolumn{2}{|c|}{ Peso seco de flores $(\mathrm{g})$} \\
\hline & \multirow[b]{2}{*}{9} & \multirow[b]{2}{*}{13} & & & \multirow[b]{2}{*}{9} & \multirow[b]{2}{*}{13} \\
\hline & & & 9 & 13 & & \\
\hline 2.5 & 6.8 & 6.73 & 4.8 & 4.73 & 8.8 & 8.73 \\
\hline 4 & 6.26 & 6.03 & 4.26 & 3.96 & 8.26 & 7.86 \\
\hline 6 & 6.33 & 6.86 & 3.96 & 4.86 & 8.3 & 8.86 \\
\hline 8 & 6.2 & 6.86 & 4.2 & 4.86 & 8.2 & 8.86 \\
\hline Tendencia & $\mathrm{L}^{*}$ & $\mathrm{Q}^{*}$ & $\mathrm{~L}^{*}$ & $\mathrm{Q}^{*}$ & $\mathrm{~L}^{*}$ & $\mathrm{Q}^{*}$ \\
\hline Anova & & & & & & \\
\hline $\mathrm{CE}$ & \multicolumn{2}{|c|}{ ns } & \multicolumn{2}{|c|}{ ns } & \multicolumn{2}{|c|}{$\mathrm{ns}$} \\
\hline $\mathrm{Ca}$ & \multicolumn{2}{|c|}{ ns } & \multirow{2}{*}{\multicolumn{2}{|c|}{ ns }} & \multirow{2}{*}{\multicolumn{2}{|c|}{$\mathrm{ns}$}} \\
\hline $\mathrm{CE} * \mathrm{Ca}$ & \multicolumn{2}{|c|}{ ns } & & & & \\
\hline
\end{tabular}

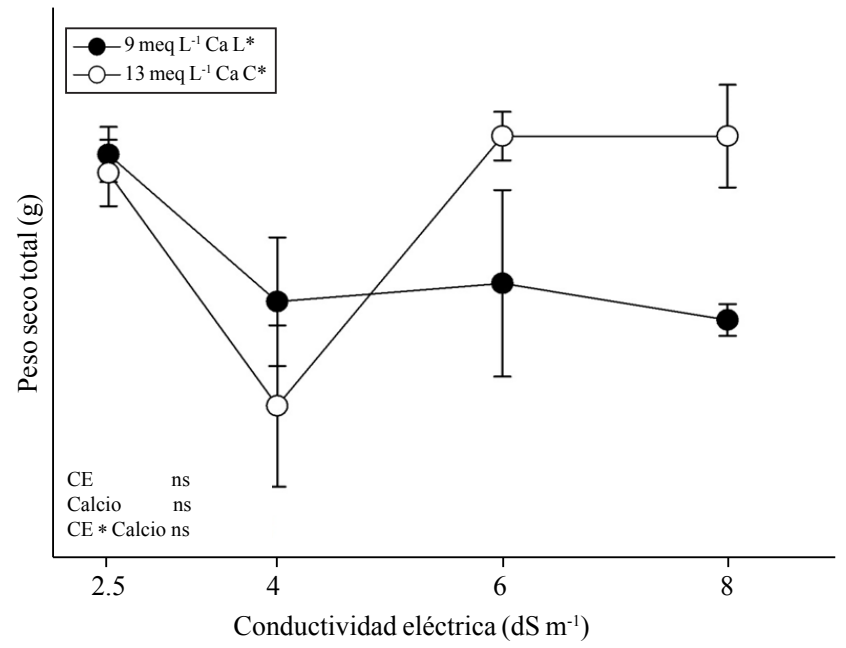

Figura 2. Efecto de la conductividad eléctrica $(\mathrm{CE})$, la concentración de calcio $(C a)$ en la solución nutritiva e interacción entre ambos factores sobre el peso seco total en lisianthus. $L, C=$ tendencia lineal, cúbica, *, ns = significativo con $p<0.05$ y no significativo, respectivamente. Las barras corresponden al error estándar de la media $(\mathrm{n}=3)$.

Figure 2. Effect of the electrical conductivity (EC), the concentration of calcium $(\mathrm{Ca})$ in the nutrient solution and interaction between the two factors on the total dry weight in lisianthus. $\mathrm{L}, \mathrm{C}=$ linear trend, cubic, *, ns= significant with $p<0.05$ and non-significant, respectively. The bars correspond to the mean standard error $(n=3)$.

El número de flores no fue afectado por los niveles de $\mathrm{Ca}$; sin embargo, al elevar la $\mathrm{CE} \mathrm{a} 4 \mathrm{dS} \mathrm{m}^{-1}$ se detectó un efecto promotor en la formación de flores, el cual ya no es detectado
The dry weight of stems, leaves and flowers (Table 2) and total dry weight (Figure 2) showed a similar response. 9 meq $\mathrm{L}^{-1} \mathrm{Ca}$ a linear decrease of the total dry weight, especially when the EC $4 \mathrm{dS} \mathrm{m}^{-1}$ rises was filed; this decrease is also observed in plants treated with supplemental $\mathrm{Ca}$, however, the cubic trend indicates a recovery occurs in the total biomass when the EC increased to 6 and $8 \mathrm{dS} \mathrm{m}^{-1}$, virtually reaching levels comparable to those of the plant biomass in the control treatment (Figure 2).

The number of flowers was not affected by the levels of $\mathrm{Ca}$; however, to raise the $\mathrm{CE}$ to $4 \mathrm{dS} \mathrm{m}{ }^{-1}$ a promoter effect on the formation of flowers, which is no longer detected with higher levels (Figure 3). Also, the size of the flowers showed a positive effectassociated with the increased plant CE $9 \mathrm{meq} \mathrm{L}^{-1}$ $\mathrm{Ca}$ as the flowers were of greater diameter when the solution had a high EC compared to control plants (Figure4). In treated with additional $\mathrm{Ca}$ plants the same trend was observed since the flowers were smaller diameter with increasing EC, but nevertheless the size of the flowers was similar to the control plants until the $\mathrm{EC}$ was higher than $6 \mathrm{dS} \mathrm{m}^{-1}$.

The photosynthetic pigment content and carotenoids showed a similar increase CE (Figure 3 ) response. In this case were cubic trends as with solutions $6 \mathrm{dS} \mathrm{m}^{-1}$ was observed a decrease in the concentration of chlorophyll and carotenoids, which subsequently recovered when the plants were irrigated with solutions of $8 \mathrm{dS}^{-1}$. Plants treated with additional $\mathrm{Ca}$ managed to maintain a higher concentration of pigments compared to those treated with $9 \mathrm{meq} \mathrm{L}^{-1}$ of Ca when the EC of the solution was 6 and $8 \mathrm{dS} \mathrm{m} \mathrm{m}^{-1}$. 
con niveles más elevados (Figura 3). Asimismo, el tamaño de las flores mostró un efecto positivo asociado con el aumento de laCE en plantas con $9 \mathrm{meq} \mathrm{L}^{-1} \mathrm{de}$ Ca puesto que las flores resultaron de mayor diámetro cuando la solución tenía una alta $\mathrm{CE}$ en comparación con las plantas testigo (Figura 4). En plantas tratadas con Ca adicional no se observó la misma tendencia puesto que las flores resultaron de menor diámetro conforme aumentaba la CE, pero a pesar de ello el tamaño de las flores fue similar al de las plantas testigo hasta que la CE fue mayor de $6 \mathrm{dS} \mathrm{m}^{-1}$.

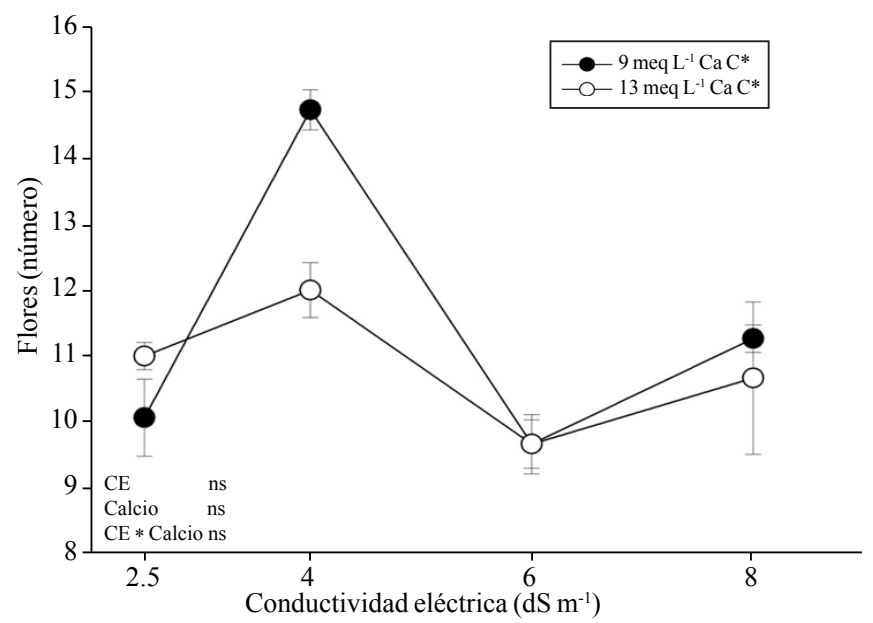

Figura 3. Efecto de la conductividad eléctrica (CE) y la concentración de calcio (Ca) en la solución nutritiva e interacción entre ambos factores sobre el número de flores en lisianthus. $\mathrm{C}=$ tendencia cúbica, *, ns $=$ significativo con $p<0.05$ y no significativo, respectivamente. Las barras corresponden al error estándar de la media $(\mathrm{n}=3)$.

Figure 3. Effect of electrical conductivity (EC) and the concentration of calcium $(\mathrm{Ca})$ in the nutrient solution and interaction between the two factors on the number of flowers in lisianthus. $C=$ significant with $p<0.05$ and non-significant, respectively cube trend *, ns= The bars correspond to the mean standard error $(n=3)$.

El contenido de pigmentos fotosintéticos así como de carotenoides mostró una respuesta similar al aumentar la CE (Cuadro 3). En este caso las tendencias fueron cúbicas ya que con soluciones de $6 \mathrm{dS} \mathrm{m}^{-1}$ se observó una disminución en la concentración de clorofilas y carotenoides, la cual posteriormente se recuperó cuando las plantas se irrigaron con soluciones de $8 \mathrm{dSm}^{-1}$. Las plantas tratadas con $\mathrm{Ca}$ adicional logaron mantener una mayor concentración de los pigmentos en comparación con aquellas tratadas con $9 \mathrm{meq}$ $\mathrm{L}^{-1}$ de Ca cuando la CE de la solución fue de 6 y $8 \mathrm{dS} \mathrm{m}^{-1}$.

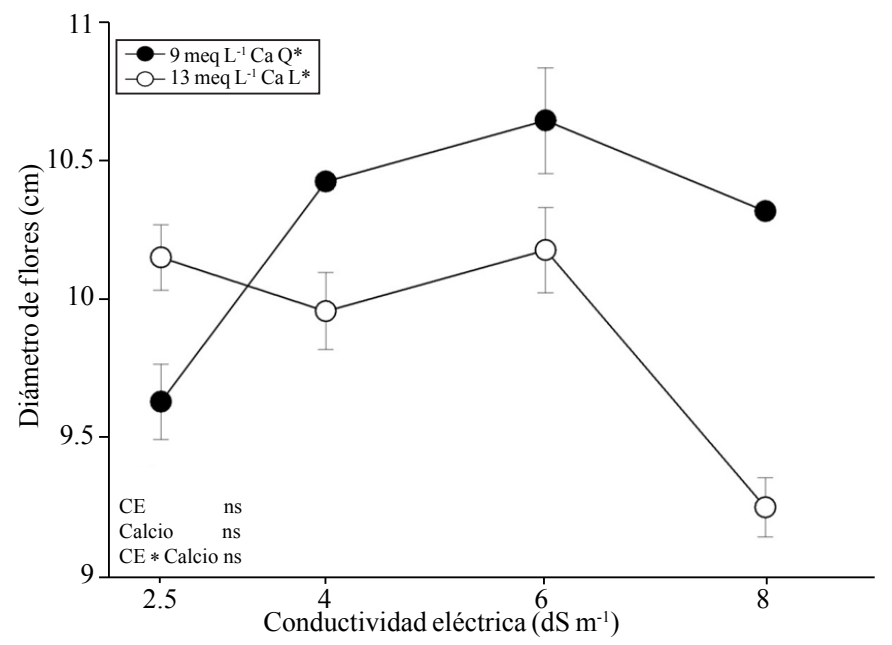

Figura 4. Efecto de la conductividad eléctrica (CE) y la concentración de calcio ( $\mathrm{Ca}$ ) en la solución nutritiva e interacción entre ambos factores sobre el diámetro de flores en lisianthus. $L, Q=$ tendencia lineal, cuadrática, *, ns = significativo con $p<0.05$ y no significativo, respectivamente. Las barras corresponden al error estándar de la media $(\mathrm{n}=3)$.

Figure 4. Effect of the electrical conductivity (EC) and the concentration of calcium $(\mathrm{Ca})$ in the nutrient solution and interaction between the two factors on the lisianthus flower diameter. $\mathrm{L}, \mathrm{Q}=$ linear trend, quadratic, *, ns= significant with $p<0.05$ and nonsignificant, respectively. The bars correspond to the mean standard error $(n=3)$.

Regardless of the concentration of Ca in the nutrient solution, the EC quadratically affected the rate of net photosynthesis to occur a decrease when the EC was $4 \mathrm{dS} \mathrm{m}^{-1}$ (Table 4); however, to increase up to 6 and $8 \mathrm{dS} \mathrm{m}^{-1}$, photosynthesis rates comparable to recover plants with low levels CE. In general, leaf conductance and transpiration rate decreased as the EC, regardless of the level of Ca was increased in the nutrient solution (Table 4).

The CRA in young and mature leaves decreased plants with 9 meq $\mathrm{L}^{-1}$ of $\mathrm{Ca}$; however, supplemented by additional $\mathrm{Ca}$ plants an increase in CRA, which exceeds the plant 9 meq $\mathrm{L}^{-1}$ when treated with solutions of EC larger than $4 \mathrm{dS} \mathrm{m}^{-1}$ (Table 4) was observed. The response observed in the CRA was associated with $\Psi$ h of young and mature leaves as similar trends (Table 5) were observed.

The concentration of $\mathrm{N}, \mathrm{K}, \mathrm{Ca}$ and $\mathrm{Mg}$ in the aerial part of the plants was affected by the EC, while the P concentration was affected by the interaction between the EC and the 
Cuadro 3. Concentración de carotenoides y clorofila en hojas de la parte media de la planta en lisianthus en función de la concentración de calcio (Ca) y la conductividad eléctrica (CE) en la solución nutritiva.

Table 3. Concentration of carotenoids and chlorophyll in leaves of the middle part of the plant in lisianthus in function of the concentration of calcium (Ca) and electrical conductivity (EC) in the nutrient solution.

\begin{tabular}{|c|c|c|c|c|c|c|c|c|}
\hline \multirow{3}{*}{$\begin{array}{c}\mathrm{CE} \\
\left(\mathrm{dS} \mathrm{\textrm {m } ^ { - 1 }}\right)\end{array}$} & \multicolumn{2}{|c|}{$\begin{array}{l}\text { Carotenoides } \\
\quad\left(\mu \mathrm{g} \mathrm{g}^{-1}\right)\end{array}$} & \multicolumn{2}{|c|}{$\begin{array}{l}\text { Clorofila total } \\
\qquad\left(\mathrm{mg} \mathrm{g}^{-1}\right)\end{array}$} & \multicolumn{2}{|c|}{$\begin{array}{l}\text { Clorofila a } \\
\left(\mathrm{mg} \mathrm{g}^{-1}\right)\end{array}$} & \multicolumn{2}{|c|}{$\begin{array}{l}\text { Clorofila b } \\
\left(\mathrm{mg} \mathrm{g}^{-1}\right)\end{array}$} \\
\hline & \multicolumn{8}{|c|}{$\mathrm{Ca}\left(\right.$ meq $\left.\mathrm{L}^{-1}\right)$} \\
\hline & 9 & 13 & 9 & 13 & 9 & 13 & 9 & 13 \\
\hline 2.5 & 108 & 103 & 2.79 & 2.85 & 0.79 & 0.8 & 0.41 & 0.43 \\
\hline 4 & 110 & 108 & 2.97 & 3.08 & 0.82 & 0.83 & 0.46 & 0.49 \\
\hline 6 & 47 & 71 & 1.28 & 2.05 & 0.39 & 0.61 & 0.16 & 0.27 \\
\hline 8 & 87 & 100 & 2.32 & 2.79 & 0.68 & 0.78 & 0.32 & 0.41 \\
\hline Tendencia & $\mathrm{C}^{* * *}$ & $\mathrm{C}^{* * *}$ & $\mathrm{C}^{* * *}$ & $\mathrm{C}^{* * *}$ & $\mathrm{C}^{* * *}$ & $\mathrm{C}^{* * *}$ & $\mathrm{C}^{* * *}$ & $\mathrm{C}^{* * *}$ \\
\hline \multicolumn{9}{|l|}{ Anova } \\
\hline $\mathrm{CE}$ & \multicolumn{2}{|c|}{ ns } & \multicolumn{2}{|c|}{$* * *$} & \multicolumn{2}{|c|}{$* * *$} & \multicolumn{2}{|c|}{$* * *$} \\
\hline $\mathrm{Ca}$ & \multirow{2}{*}{\multicolumn{2}{|c|}{$\underset{* * *}{\mathrm{~ns}}$}} & \multirow{2}{*}{\multicolumn{2}{|c|}{$\begin{array}{l}* * * \\
* * *\end{array}$}} & \multirow{2}{*}{\multicolumn{2}{|c|}{$\begin{array}{l}* * * \\
* * *\end{array}$}} & \multirow{2}{*}{\multicolumn{2}{|c|}{$\begin{array}{l}* * * \\
* * *\end{array}$}} \\
\hline $\mathrm{CE} * \mathrm{Ca}$ & & & & & & & & \\
\hline
\end{tabular}

Independientemente de la concentración de $\mathrm{Ca}$ en la solución nutritiva, la CE afectó cuadráticamente la tasa de fotosíntesis neta al presentarse una disminución cuando la CE fue de $4 \mathrm{dS} \mathrm{m}^{-1}$ (Cuadro 4); sin embargo, al aumentarla hasta 6 y $8 \mathrm{dS} \mathrm{m}^{-1}$, la tasa de fotosíntesis se recupera a niveles comparables al de las plantas con baja CE. En general, la conductancia de la hoja así como la tasa de transpiración disminuyeron conforme se aumentaba la $\mathrm{CE}$, independientemente del nivel de Ca en la solución nutritiva (Cuadro 4). concentration of $\mathrm{Ca}($ Table 6). In plants treated with solutions of $9 \mathrm{meq} \mathrm{L}^{-1} \mathrm{Ca}$, the concentration of $\mathrm{N}, \mathrm{P}$ and $\mathrm{Mg}$ is elevated by increasing the $\mathrm{CE}$ to 4 or $6 \mathrm{dS} \mathrm{m}^{-1}$ but higher levels were associated with a reduction. In contrast, $\mathrm{K}$ and $\mathrm{Ca}$ with $\mathrm{CE}$ moderately decreased, although the concentration of $\mathrm{K}$ is recovered when a higher EC was applied.

In plants treated with 13 meq $\mathrm{L}^{-1}$ of $\mathrm{Ca}, \mathrm{N}, \mathrm{P}$ and $\mathrm{Mg}$ decreased the EC rise to $6 \mathrm{dS} \mathrm{m}^{-1}$; however, with higher EC concentration of these nutrients is partially or completely

Cuadro 4. Fotosíntesis, conductancia, traspiración, contenido relativo de agua (CRA) en hoja joven (HJ) y madura (HM) de lisianthus en función de la concentración de calcio (Ca) y la conductividad eléctrica (CE) en la solución nutritiva. Table 4. Photosynthesis, conductance, transpiration, relative water content $(\mathrm{RWC})$ in young $(\mathrm{HJ})$ and mature leaf $(\mathrm{HM})$ of lisianthus depending on the concentration of calcium (Ca) and electrical conductivity (EC) in the nutrient solution.

\begin{tabular}{|c|c|c|c|c|c|c|c|c|c|c|}
\hline \multirow{3}{*}{$\begin{array}{c}\mathrm{CE} \\
\left(\mathrm{dS} \mathrm{m} \mathrm{m}^{-1}\right)\end{array}$} & \multicolumn{2}{|c|}{$\begin{array}{c}\text { Fotosíntesis } \\
\left(\mu \mathrm{mol} \mathrm{CO} \mathrm{C}_{2}\right)^{-2}\end{array}$} & \multicolumn{2}{|c|}{$\begin{array}{l}\text { Conductancia } \\
\left(\mathrm{mol} \mathrm{H}_{2} \mathrm{O} \mathrm{m}^{2} \mathrm{~s}^{-1}\right)\end{array}$} & \multirow{2}{*}{\multicolumn{2}{|c|}{$\begin{array}{c}\text { Traspiración } \\
\left(\mathrm{mmol} \mathrm{H}_{2} \mathrm{O} \mathrm{m}^{2} \mathrm{~s}^{-1}\right)\end{array}$}} & \multicolumn{2}{|c|}{$\begin{array}{c}\text { CRA HJ } \\
(\%)\end{array}$} & \multicolumn{2}{|c|}{$\begin{array}{c}\text { CRAHM } \\
(\%)\end{array}$} \\
\hline & \multirow[b]{2}{*}{9} & & & & & & & & & \\
\hline & & 13 & 9 & 13 & 9 & 13 & 9 & 13 & 9 & 13 \\
\hline 2.5 & 11.5 & 12.2 & 0.274 & 0.312 & 10.2 & 10.5 & 88.1 & 76 & 70.4 & 77.6 \\
\hline 4 & 10.1 & 9.4 & 0.308 & 0.245 & 10 & 9.6 & 75 & 80.3 & 75.6 & 81.9 \\
\hline 6 & 10.6 & 11.4 & 0.241 & 0.258 & 9.2 & 9.6 & 69.7 & 79.2 & 75.5 & 73.3 \\
\hline 8 & 12.4 & 12 & 0.252 & 0.219 & 9.8 & 8.6 & 73.3 & 79.8 & 76.8 & 69.9 \\
\hline Tendencia & $\mathrm{Q}^{*}$ & $\mathrm{Q}^{*}$ & $\mathrm{C}^{*}$ & $\mathrm{~L}^{* *}$ & $\mathrm{Q}^{*}$ & $\mathrm{~L}^{*}$ & $\mathrm{Q}^{*}$ & $\mathrm{~L}^{*}$ & $C^{* * *}$ & $C^{* * *}$ \\
\hline \multicolumn{11}{|l|}{ Anova } \\
\hline $\mathrm{CE}$ & \multicolumn{2}{|c|}{ ns } & \multicolumn{2}{|c|}{ ns } & \multicolumn{2}{|c|}{ ns } & \multicolumn{2}{|c|}{ ns } & \multicolumn{2}{|c|}{ ns } \\
\hline $\mathrm{Ca}$ & \multicolumn{2}{|c|}{ ns } & \multirow{2}{*}{\multicolumn{2}{|c|}{ ns }} & \multirow{2}{*}{\multicolumn{2}{|c|}{$\mathrm{ns}$}} & \multirow{2}{*}{\multicolumn{2}{|c|}{ ns }} & \multirow{2}{*}{\multicolumn{2}{|c|}{$\begin{array}{c}\mathrm{ns} \\
* * *\end{array}$}} \\
\hline $\mathrm{CE} * \mathrm{Ca}$ & \multicolumn{2}{|c|}{ ns } & & & & & & & & \\
\hline
\end{tabular}

$\mathrm{L}, \mathrm{Q}, \mathrm{C}=$ tendencia lineal, cuadrática y cúbica, respectivamente; $\mathrm{ns}=*$, ***= no significativo y significativo con $p<0.05$, y 0.001 , respectivamente. 
El CRA en hojas jóvenes y maduras disminuyó en plantas con 9 meq L $^{-1}$ de Ca; sin embargo, en plantas suplementadas con $\mathrm{Ca}$ adicional se observó un aumento en el CRA, el cual supera al de las plantas con $9 \mathrm{meq} \mathrm{L}^{-1}$ cuando se trataron con soluciones de CE mayor de $4 \mathrm{dS} \mathrm{m}^{-1}$ (Cuadro 4). La respuesta observada en el CRA estuvo asociada con el $\Psi$ h de las hojas jóvenes y maduras pues se observaron tendencias similares (Cuadro 5).

La concentración de N, K, Ca y Mg en la parte aérea de las plantas fue afectada por la $\mathrm{CE}$, en tanto que la concentración de $\mathrm{P}$ fue afectada por la interacción entre la CE y la concentración de $\mathrm{Ca}$ (Cuadro 6). En plantas tratadas con soluciones de $9 \mathrm{meq} \mathrm{L}^{-1} \mathrm{deCa}$, la concentración de $\mathrm{N}, \mathrm{PyMg}$ se eleva al aumentar la $\mathrm{CE}$ hasta 4 o $6 \mathrm{dS} \mathrm{m}^{-1}$, pero niveles más elevados estuvieron asociados con una reducción. En contraste, el K y Ca disminuyeron con CE moderada, aunque la concentración de $\mathrm{K}$ se recuperó cuando se aplicó una mayor CE.

En plantas tratadas con 13 meq $\mathrm{L}^{-1}$ de $\mathrm{Ca}$, el $\mathrm{N}, \mathrm{P}$ y $\mathrm{Mg}$ disminuyeron al elevarse la CE hasta $6 \mathrm{dS} \mathrm{m}^{-1}$; sin embargo, con una mayor $\mathrm{CE}$ la concentración de estos nutrimentos se recuperó parcial o totalmente en comparación con las plantas irrigadas con soluciones de $2.5 \mathrm{dS} \mathrm{m}^{-1}$. La concentración de $\mathrm{K}$ y Ca tiende a aumentar cuando se eleva la CE hasta 4 $\mathrm{dS} \mathrm{m}{ }^{-1}$, pero con $6 \mathrm{dS} \mathrm{m}^{-1}$ se detectó una reducción que es posteriormente recuperada parcialmente en plantas crecidas con soluciones de $8 \mathrm{dS} \mathrm{m}^{-1}$. recovered compared to the plants irrigated with solutions of $2.5 \mathrm{dS} \mathrm{m}^{-1}$. The concentration of $\mathrm{K}$ and $\mathrm{Ca}$ tends to increase when the CE rises to $4 \mathrm{dS} \mathrm{m}^{-1}$, but with $6 \mathrm{dS} \mathrm{m}^{-1}$ which is then reduced in plants grown partially recovered from solutions of $8 \mathrm{dS} \mathrm{m}^{-1}$ was detected.

Cuadro 5. Potencial hídrico ( $\Psi$ h) en hojas jóvenesy maduras de lisianthus en función de la concentración de calcio (Ca) y la conductividad eléctrica (CE) en la solución nutritiva.

Table 5. Water potential $(\Psi h)$ in young and mature leaves of lisianthus in function of the concentration of calcium (Ca) and electrical conductivity (EC) in the nutrient solution.

\begin{tabular}{|c|c|c|c|c|}
\hline \multirow{3}{*}{ 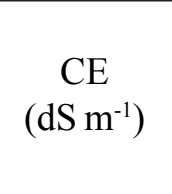 } & \multicolumn{2}{|c|}{$\begin{array}{l}\Psi \text { h hojas maduras } \\
(\mathrm{MPa})\end{array}$} & \multicolumn{2}{|c|}{$\begin{array}{c}\text { Yh hojas jóvenes } \\
(\mathrm{MPa})\end{array}$} \\
\hline & \multicolumn{4}{|c|}{$\mathrm{Ca}\left(\mathrm{meq} \mathrm{L}^{-1}\right)$} \\
\hline & 9 & 13 & 9 & 13 \\
\hline 2.5 & -1.37 & -0.87 & -0.71 & -1.23 \\
\hline 4 & -0.78 & -0.91 & -0.68 & -0.36 \\
\hline 6 & -0.51 & -0.70 & -0.66 & -0.86 \\
\hline 8 & -0.65 & -0.97 & -0.67 & -0.83 \\
\hline Tendencia & $\mathrm{L}^{*}$ & $\mathrm{Q}^{*}$ & $\mathrm{Q}^{*}$ & $\mathrm{C}^{*}$ \\
\hline \multicolumn{5}{|l|}{ Anova } \\
\hline $\mathrm{CE}$ & \multicolumn{2}{|c|}{ ns } & \multicolumn{2}{|c|}{$\mathrm{ns}$} \\
\hline $\mathrm{Ca}$ & \multicolumn{2}{|c|}{ ns } & \multicolumn{2}{|c|}{ ns } \\
\hline $\mathrm{CE} * \mathrm{Ca}$ & \multicolumn{2}{|c|}{ ns } & \multicolumn{2}{|c|}{ ns } \\
\hline
\end{tabular}

Cuadro 6. Contenido de macronutrientes $\left(\mathrm{mmol} \mathrm{kg}^{-1}\right)$ en parte aérea de lisianthus en función de la concentración de calcio (Ca) y la conductividad eléctrica (CE) en la solución nutritiva.

Table 6. Macronutrient content $\left(\mathrm{mmol} \mathrm{kg}^{-1}\right)$ in aerial part of lisianthus depending on the concentration of calcium (Ca) and electrical conductivity (EC) in the nutrient solution.

\begin{tabular}{|c|c|c|c|c|c|c|c|c|c|c|}
\hline \multirow{3}{*}{$\begin{array}{c}\mathrm{CE} \\
\left(\mathrm{dS} \mathrm{m}^{-1}\right)\end{array}$} & \multicolumn{2}{|c|}{ Nitrógeno } & \multicolumn{2}{|c|}{ Fósforo } & \multicolumn{2}{|c|}{ Potasio } & \multicolumn{2}{|c|}{ Calcio } & \multicolumn{2}{|c|}{ Magnesio } \\
\hline & \multicolumn{10}{|c|}{$\mathrm{Ca}\left(\mathrm{meq} \mathrm{L} \mathrm{L}^{-1}\right)$} \\
\hline & 9 & 13 & 9 & 13 & 9 & 13 & 9 & 13 & 9 & 13 \\
\hline 2.5 & 1232 & 1669 & 50 & 53 & 492 & 398 & 38 & 32 & 151 & 164 \\
\hline 4 & 1383 & 1367 & 70 & 46 & 447 & 484 & 32 & 35 & 181 & 137 \\
\hline 6 & 1359 & 813 & 57 & 43 & 380 & 314 & 28 & 24 & 159 & 112 \\
\hline 8 & 1258 & 1291 & 46 & 61 & 450 & 366 & 28 & 25 & 147 & 157 \\
\hline Tendencia & $\mathrm{Q}^{*}$ & $\mathrm{Q}^{*}$ & $\mathrm{Q}^{*}$ & $\mathrm{Q}^{*}$ & $\mathrm{Q}^{*}$ & $\mathrm{C}^{*}$ & $\mathrm{~L}^{*}$ & $\mathrm{Q}^{*}$ & $\mathrm{Q}^{*}$ & $\mathrm{Q}^{*}$ \\
\hline Anova & & & & & & & & & & \\
\hline $\mathrm{CE}$ & \multicolumn{2}{|c|}{$* *$} & \multicolumn{2}{|c|}{ ns } & \multicolumn{2}{|c|}{$* * *$} & \multicolumn{2}{|c|}{ * } & \multicolumn{2}{|c|}{$*$} \\
\hline $\mathrm{Ca}$ & \multirow{2}{*}{\multicolumn{2}{|c|}{ ns }} & \multicolumn{2}{|c|}{ ns } & \multicolumn{2}{|c|}{$\mathrm{ns}$} & \multicolumn{2}{|c|}{ ns } & \multicolumn{2}{|c|}{$\mathrm{ns}$} \\
\hline $\mathrm{CE} * \mathrm{Ca}$ & & & \multicolumn{2}{|c|}{$*$} & \multicolumn{2}{|c|}{ ns } & \multicolumn{2}{|c|}{ ns } & \multicolumn{2}{|c|}{ ns } \\
\hline
\end{tabular}




\section{Discusión}

Se reporta que el principal efecto de la salinidad es un retraso del crecimiento de las plantas a través de su influencia en varios procesos fisiológicos (Perés et al., 2008). En el presente estudio, se observó una disminución en el peso seco de todos los órganos al elevarse la CE de la solución, lo que sugiere que esta especie no es tolerante a la salinidad. Sin embargo, cuando las plantas fueron sometidas a niveles altos de CE se presentó una recuperación en la acumulación de biomasa si las soluciones nutritivas se suplementaron con $\mathrm{Ca}$ adicional, sugiriendo que este nutrimento puede disminuir el efecto del estrés salino. La tolerancia al estrés biótico o abiótico impartida por el Ca se ha asociado a un aumento temporal en la concentración de Ca intracelular, el cual actúa como mensajero secundario en la generación de respuestas adaptativas para contrarrestar los efectos nocivos (Batistič y Kudla, 2010).

El efecto del Ca en la restauración de la biomasa en condiciones de alta $\mathrm{CE}$ no estuvo asociado con la tasa de fotosíntesis, transpiración o conductancia estomática. Sin embargo, el lisianthus fisiológicamente si mostró respuestas adaptativas a la alta salinidad ya que, independientemente de la concentración de $\mathrm{Ca}$, la tasa de fotosíntesis no fue afectada al aumentar la CE. En el presente estudio, la tasa de fotosíntesis se mantuvo estable a pesar de la disminución de los pigmentos fotosintéticos, lo cual coincide con lo reportado por Argentel et al. (2006), quienes señalan que la salinidad afecta la concentración de clorofila debido a la destrucción de los cloroplastos y al aumento en la actividad de la clorofilasa, mientras que los carotenoides son menos afectados. Sin embargo, la adición de Ca suplementario si tuvo un efecto benéfico ya que la concentración de clorofilas a, b y total, así como de carotenoides, superó a la obtenida por plantas con menos $\mathrm{Ca}$ en condiciones de alta $\mathrm{CE}$, presentándose incluso una recuperación en la concentración de tales pigmentos con alta CE. Xu et al. (2013) y Wan et al. (2011) reportan que en Zoyzia y en Brassica nappus, respectivamente, se presenta un incremento en la concentración de pigmentos fotosintéticos y en la tasa de fotosíntesis cuando se eleva la concentración de Ca bajo condiciones de estrés hídrico o por exceso de cadmio.

La absorción de agua por parte de las raíces se dificulta debido al efecto osmótico de la salinidad (Munns y Tester, 2008), alterando las relaciones hídricas de la planta. La

\section{Discussion}

It is reported that the main effect of salinity is a stunting of plants through its influence on various physiological processes (Perés et al., 2008). In the present study, a decrease was observed in the dry weight of all organs to raise the EC of the solution, suggesting that this species is not tolerant to salinity. However, when the plants were subjected to high levels, EC recovery occurred in biomass accumulation if the nutrient solutions were supplemented with additional $\mathrm{Ca}$, suggesting that this nutrient may decrease the effect of salt stress. Tolerance to biotic or abiotic stress imparted by the Ca has been associated with a temporary increase in intracellular Ca concentration, which acts as a second messenger in the generation of adaptive to counteract the harmful effects responses (Batistic and Kudla, 2010).

The effect of $\mathrm{Ca}$ on the restoration of biomass under high EC was not associated with the rate of photosynthesis, transpiration and stomatal conductance. However, if the physiologically lisianthus showed adaptive to high salinity and that regardless of the concentration of $\mathrm{Ca}$, photosynthetic rate was unaffected by increasing the $\mathrm{CE}$ responses. In the present study, the rate of photosynthesis was stable despite the decline in photosynthetic pigments, which agrees with that reported by Argentel et al. (2006), who indicated that salinity affects chlorophyll concentration due to destruction of chloroplasts and increased chlorophyllase activity, while carotenoids are less affected. However, the addition of supplemental Ca had a beneficial effect as the concentration of chlorophyll $\mathrm{a}, \mathrm{b}$ and total carotenoid and exceeded that achieved by plants with less $\mathrm{Ca}$ under high EC, presenting even a recovery in concentration of such pigments with high EC. Xu et al. (2013) and Wan et al. (2011) report that in Zoyzia and Brassica nappus, respectively, an increase occurs in the concentration of photosynthetic pigments and photosynthetic rate when the concentration of $\mathrm{Ca}$ under conditions of water stress or excess amounts of cadmium.

Water absorption by the roots is difficult due to the osmotic effect of salinity (Munns and Tester, 2008), altering water relations of the plant. The decrease in CRA at rising EC detected in young leaves of lisianthus match results reported by Kholova et al. (2010); however, in this study, the reduction in the CRA was counteracted by the addition 
disminución en el CRA al elevarse la CE detectado en hojas jóvenes de lisianthus coincide con resultados en maíz reportados por Kholova et al. (2010); sin embargo, en el presente estudio, la disminución en el CRA fue contrarrestada por la adición de Ca suplementario. El mantenimiento delCRAen hojas jóvenes estuvo relacionado con la acumulación de una mayor biomasa por parte de las plantas tratadas con Ca adicional, lo cual a su vez se relacionó con un mayor $\Psi \mathrm{h}$ de tales hojas. El mayor CRA y $\Psi$ h en plantas suplementadas con $\mathrm{Ca}$ adicional son indicadores de que el no efecto en la acumulación de biomasa estuvo relacionado con el mejor estado hídrico de las plantas, lo que pudo ser causado por un aumento en la concentración de osmolitos (Bárcenas-Abogado et al., 2002), como la prolina y glicin-betaina (Kolova et al., 2010), o bien al papel del Ca en el transporte de agua en raíces de plantas sometidas a alta concentración de sales (Azaizeh et al., 1991). La menor tasa de transpiración y conductancia de las hojas detectadas en el presente estudio al elevarse la CE debieron haber permitido también una mejoría en el estado hídrico de las plantas al reducirse la pérdida de agua.

Valdéz-Aguilar et al. (2011) mencionan que el estrés por salinidad causa una reducción en la acumulación de $\mathrm{K}$ en varias especies ornamentales de jardín, lo cual es debido a la competencia con el $\mathrm{Na}$, un ion frecuentemente encontrado en agua con alta salinidad. La concentración de $\mathrm{Ca}$ en los tejidos de plantas bajo condiciones de alta salinidad a su vez es disminuida debido al desplazamiento causado por el exceso de $\mathrm{Na}$ (Cramer etal., 1985). Rengel(1992)menciona que la adición de $\mathrm{Ca}$ suplementario en plantas bajo estrés salino puede reducir marcadamente la absorción de iones tóxicos como el $\mathrm{Na}$ y el $\mathrm{Cl}$, e incrementar la absorción de $\mathrm{K}$ y Ca, coadyuvando a contrarrestar los efectos adversos provocados por la salinidad. En el presente estudio no se detectó que la adición de Ca suplementario haya elevado la extracción y acumulación de nutrimentos en los tejidos; sin embargo, cuando las plantas fueron sometidas al nivel más alto de $\mathrm{CE}\left(8 \mathrm{dS} \mathrm{m}^{-1}\right)$ y se les aplicó Ca adicional, si se observó una recuperación de la concentración de $\mathrm{N}, \mathrm{P}$, $\mathrm{K}, \mathrm{y} \mathrm{Mg}$, llegando incluso a ser comparable o mayor al de las plantas irrigadas con soluciones de CE normal. Lo anterior permite suponer que aunque el Ca suplementario no eleva la concentración de Ca en los tejidos vegetales, este pudiese estar manteniendo la integridad de las membranas celulares, lo que resulta en una mejoría en la absorción nutrimental, como lo demostraron Tuna et al. (2007) en tomate. of extra Ca. Maintaining the CRA in young leaves was associated with greater biomass accumulation by plants treated with additional $\mathrm{Ca}$, which in turn is associated with an increased $\Psi \mathrm{h}$ of such leaves. The largest CRA and $\Psi \mathrm{h}$ in plants supplemented with additional $\mathrm{Ca}$ are indicators that the no effect on biomass accumulation was associated with better water status of the plants, which could be caused by an increase in the concentration of osmolytes (BarcenasAbogado et al., 2002), such as proline and glycine-betaine (Kolova et al., 2010) or the role of $\mathrm{Ca}$ in water transport in plant roots under high salt (Azaizeh et al., 1991). The lower rate of transpiration and leaf conductance detected in the present study to raise the EC should have also allowed an improvement in the water status of plants by reducing water loss.

Valdéz-Aguilar et al. (2011) mentioned that the salinity stress causes a reduction in the accumulation of $\mathrm{K}$ in various ornamentals, which is due to the competition with the $\mathrm{Na}$ ion frequently encountered in high salinity water. The Ca concentration in plant tissues under conditions of high salinity in turn is reduced due to the displacement caused by the excess of $\mathrm{Na}$ (Cramer et al., 1985). Rengel (1992) mentioned that the addition of supplemental $\mathrm{Ca}$ in plants under salt stress can markedly reduce the absorption of toxic ions such as $\mathrm{Na}$ and $\mathrm{Cl}$, and increase the absorption of $\mathrm{K}$ and $\mathrm{Ca}$, helping to counteract the adverse effects of salinity. In the present study it was found that, the addition of supplemental Ca has high extractions and nutrient accumulation in tissues; however, when the plants were subjected to the highest level of EC ( $8 \mathrm{dS}$ $\mathrm{m}^{-1}$ ) and was applied additional $\mathrm{Ca}$, if a recovery of the concentration of $\mathrm{N}, \mathrm{P}, \mathrm{K}$, and $\mathrm{Mg}$, was observed even to be comparable to or greater than plants irrigated with normal $\mathrm{CE}$ solutions. This suggests that although not elevate the supplemental $\mathrm{Ca}$ concentration in plant tissues, this could be maintaining the integrity of cell membranes, resulting in an improvement in the nutrient absorption, as demonstrated by Tuna et al. (2007) in tomato.

\section{Conclusions}

Lisianthus is tolerant to high levels of salinity in irrigation water species only if additional quantities of $\mathrm{Ca}$ are added in the nutrient solution. The salinity tolerance given by $\mathrm{Ca}$ was associated with better water status of the plants, 


\section{Conclusiones}

Lisianthus es una especie tolerante a niveles altos de salinidad en el agua de riego solo si se adicionan cantidades suplementarias de Ca en la solución nutritiva. La toleranciaa la salinidad impartida por el Ca estuvo relacionada con unmejor estado hídrico de las plantas, una mejora en la concentración de pigmentos fotosintéticos, así como con una recuperación en la concentración de nutrimentos como el N, P, K y Mg.

\section{Literatura citada}

Alcántar, G. G. y Sandoval, V. 1999. Manual de análisis químico de tejido vegetal. Sociedad Mexicana de la Ciencia del Suelo. México. $156 \mathrm{p}$.

Argentel,L.; González,L.M.; Ávila,C.yAguilar,R.2006.Comportamiento del contenido relativo de agua y la concentración de pigmentos fotosintéticos de variedades de trigos cultivadas en condiciones de salinidad. Cultivos tropicales. 27:49-53.

Azaizeh, H. and Steudle, E. 1991. Effects of salinity on water transport of excised maize (Zea mays L.) roots. Plant Physiol. 97:1136-1145.

Bárcenas-Abogado, P.; Tijerina-Chávez, L.; Martínez-Garza, A.; Becerril-Román, R.; Larqué-Saavedra, A. y Colinas- León, M. T. 2002. Respuesta de tres materiales del genero Hylocereus a la salinidad sulfatico-clorhidrica. Terra. 20:123-127.

Batistič, O. and J. Kudla. 2010. Calcium: not just another ion. In: Hell, R. H. and Mendel, R. -R (Eds.). Cell Biol. Metals Nutr. Plant Cell Monographs. 17:17-54.

Cramer, G. R.; Lauchli, A. and Polito, V. S. 1985. Displacement of $\mathrm{Ca}^{2+}$ by $\mathrm{Na}^{+}$from the plasmalemma of cells. A primary response to salt stress? Plant Physiol. 79:207-211.

Hasegawa, P. M.; Bressan, R. A.; Zhu, J. K. and Bohnert, H. J. 2000. Plant cellular responses to high salinity. Ann. Rev. Plant Physiol. Plant Mol. Biol. 51:463-499.

Jeffrey, S. W. and Humphrey, G. F. 1975. New spectrophotometric equations for determining chlorophylla, bc1 and 2 in higherplants, algae and natural phytoplankton. Biochem Physiol. Pflanz, 167:191-194.

Kholova, J.; Sairam, R. K. and Meena, R. C. 2010. Osmolytes and metal ions accumulation, oxidative stress and antioxidant enzymes activity as determinants of salinity stress tolerance in maize genotypes. Acta Physiologiae Plantarum. 32:477-486. an improvement in the concentration of photosynthetic pigments, as well as a recovery in the concentration of nutrients like $\mathrm{N}, \mathrm{P}, \mathrm{K}$ and $\mathrm{Mg}$.

End of the English version

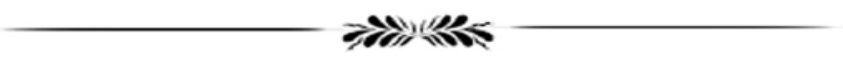

Kiamohammadi, M. 2011. The effects of different floral preservative solutions on vase life of lisianthus cut flowers. J. Ornamental Hortic. Plants. 1:115-122.

Marschner H. 1995. Mineral nutrition of higher plants. Ed. Academic Press. Limited, London. 889 p.

Munns, R. and Tester, M. 2008. Mechanisms of salinity tolerance. Ann. Rev. Plant. Biol. 59:651-681.

Perés, J.; Arizaleta, M. and García, G. 2008. Efectos de los niveles de salinidad sobre la densidad estomática, índice estomático y el grosor foliar de la planta de Carica papaya L. Acta Botánica Venuezuelica. 31:27-34.

Rengel, Z. 1992. The role of calcium in salt toxicity. Plant Cell Environ.15:625-632.

SAS Institute, Inc. 2001. SAS/STAT software changes and enhancements through release 8.0.2. SAS Institute, Cary NC.

Steiner, A. 1968. Soilless culture. Proceedings of the $6^{\text {th }}$ Colloquium of the International Potash Institute. Florence, Italy. 324$341 \mathrm{pp}$.

Tuna, A. L.; Kaya, C.; Ashaf, M.; Altunlu, H.; Yokas, I. and Yagmur, B. 2007. The effects of calcium sulphate on growth, membrane stability and nutrient uptake of tomato plants grown under salt stress. Environ. Exp. Bot. 59:173-178.

Valdéz-Aguilar, L.A.; Grieve, C. M.; Mahar, A. R.; McGiffen, M. E. and Merhaut, D. J. 2011. Growth and ion distribution is affected by irrigation with saline water in selected landscape species grown in two consecutive growing seasons: spring-summer and fall-winter. HortScience. 46:632-642.

Valdéz-Aguilar, L. A.; Grieve, C. M. and Poss, J. 2013. Response of lisianthus to salinity: plant growth. J. Plant Nutr. 36:1605-1614.

Xu, C.; Li, X. and Zhang, L. 2013. The effect of calcium chloride on growth, photosynthesis, and antioxidant responses of Zoysia japonica under drought conditions. PLoS ONE 8:e68214. doi:10.1371/journal.pone.0068214.

Wan, G.; Najeeb, U.; Jilani, G.; Naeem, M. S. and Zhou, W. 2011. Calcium invigorates the cadmium-stressed Brassica napus L. plants by strengthening their photosynthetic system. Environ. Sci. Pollution Res. 18:1478-1486. 